Columbia Law School

Scholarship Archive

1999

\title{
The Legal and the Ethical in Legal Ethics: A Brief Rejoinder to Comments on The Practice of Justice
}

William H. Simon

Columbia Law School,wsimon@law.columbia.edu

Follow this and additional works at: https://scholarship.law.columbia.edu/faculty_scholarship

Part of the Legal Ethics and Professional Responsibility Commons

\section{Recommended Citation}

William H. Simon, The Legal and the Ethical in Legal Ethics: A Brief Rejoinder to Comments on The Practice of Justice, 51 STAN. L. REV. 991 (1999).

Available at: https://scholarship.law.columbia.edu/faculty_scholarship/878

This Article is brought to you for free and open access by the Faculty Publications at Scholarship Archive. It has been accepted for inclusion in Faculty Scholarship by an authorized administrator of Scholarship Archive. For more information, please contact scholarshiparchive@law.columbia.edu. 


\title{
The Legal and the Ethical in Legal Ethics: A Brief Rejoinder to Comments on The Practice of Justice
}

\author{
William H. Simon*
}

We have here, not the clash of opposites, but a series of family quarrels within what you might call the Party of Aspiration in legal ethics. My seven allies and I all favor lawyers' ethic of more complex judgment and more responsibility to nonclients than the currently dominant one. The differences among us are not large from the broadest perspective, but they involve issues that are quite important to the elaboration of the sort of alternative ethic we would like to see.

I am enormously grateful for the care and attention the commentators have taken. They have frequently stated my own positions better than I have and their criticisms are invariably acute. I lack both time and ideas with which to respond to many of their points. I do, however, want to address a general issue on which the commentators converge to varying degrees: To what extent should we encourage lawyers to think of the most pressing ethical issues they encounter in terms of law and justice as opposed to terms of personal morality?

Of course, the two sets of terms are not mutually exclusive. The question is rather one of emphasis. I argue in The Practice of Justice ${ }^{1}$ for an ethic of legal merit and justice. All the commentators at least speculate that I go too far in this direction at the expense of personal moral terms, and four of them are insistent on this point. Robin West, and especially David Luban, press this point in general terms, and I respond to them first. Thomas Shaffer and Anthony Alfieri press it by reference to specific alternatives-variants of communitarianism. I respond to them next. I conclude with a brief response to a different point pressed by Tanina Rostain concerning the effect of the

* Kenneth and Harle Montgomery Professor of Public Interest Law, Stanford Law School.

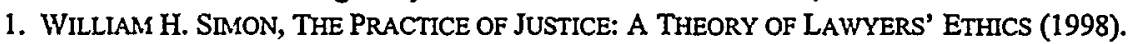
Hereinafter, all references to The Practice of Justice will be made by citation to page numbers without additional identification. 
social circumstances of practice in biasing lawyer decisions under a regime of Contextual judgment. ${ }^{2}$

\section{LUBAN AND WEST}

Luban has two sorts of complaints. One, in which West joins him, is rhetorical. The other is jurisprudential.

\section{A. Rhetoric}

My differences with Luban and West are rhetorical to the extent we share an ethical program and are simply arguing about how it can be more persuasively expressed. We all favor an ethic of complex judgment with enhanced responsibility to nonclient interests. In part, Luban and West simply fear that my insistence on legal rhetoric will be ineffective in moving us toward such an ethic or will have side effects that none of us would want.

I emphasize legal rhetoric because I want to take advantage of the tendency in the professional culture to associate law with relatively objective, rational, socially grounded judgment. At the same time, I want to escape the corresponding tendency to associate moral judgment with relativism and subjectivism. For lawyers and law students, law has weight and palpability. To deny this is nihilism. On the other hand, to deny that moral values have more than a subjective basis is the conventional wisdom. Thus, the lawyer who appeals to moral judgment against "the law" is accused of "playing God" or "imposing her own values."

My friends and teachers in Critical Legal Studies devoted a good deal of effort to extending the Realist critique of the objectivity of the legal reasoning associated with judges and demonstrating the relative "indeterminacy" of judicial doctrine. We thought that the mainstream tendency to exaggerate objectivity and determinacy gave an undeserved legitimacy to the work of the centrist/conservative judiciary. We hoped that such critique would loosen things up for Progressive politics.

I have always thought that this was an important and worthwhile project, but it was apparent to me from the beginning that the situation was quite different with lawyers' ethics. Here skepticism is the mainstream tendency. Here it is the assertion of indeterminacy and subjectivity that serves to legitimate a conservative status quo. Law is still treated as objective, but it is given a narrowed, more Positivistic portrayal then in the jurisprudence of the judicial role. And the values that one might appeal to against the conven-

2. If I do not specifically address the contributions of Deborah Rhode and Robert Gordon, it is not because I value them less, it is because I have not been able to find much in their comments with which I disagree. 
tional legal ethics responses are defined as nonlegal and moral with the derogatory connotations of insubstantiality. It seems to me a good rhetorical strategy to overcome this debilitating combination of Positivism and relativism to appeal to the more expansive and objective notion of law familiar from the jurisprudence of the judicial role.

Kandis Scott once captured this aspect of the rhetorical strategy quite succinctly, saying to me at a conference, "After we discuss how the Code handles a problem, I usually ask the students how they feel about the result. What I hear you saying is that I should ask them, 'Is it just?'” The idea was that students might feel more confidence in criticizing the conventional answer in the language of justice (and the associated language of legal merit) than in the language of, to use Luban's phrase, "passion."3

A related rhetorical reason for emphasizing legal terms is to capitalize on the emotional resonance the idea of the legal role often has for law students. Many law students, especially in elite schools, are blasé about the professional role. Others view professional credentials as meal tickets. But some are excited at the prospect of becoming lawyers. For some, the role promises dignity and social respect. Others are drawn by the idea that the role combines an established social position with idealistic exhortation and reformist opportunities. An ethic of legal merit associates itself with such attitudes and tries to draw on the energy they generate. It portrays itself as trying to work out and vindicate what excites such people about the professional role.

By contrast, an ethic of nonlegal morality often seems to be fighting against the legal role. It frequently puts itself in the position of requesting shelter from its demands. No doubt there are many situations in which this is the most sensible ethical request to make. But the request is not responsive to the concerns of the students I am talking about. They are not looking for protection from the role; they are excited by it. What they want is some concrete indication of how the role might deliver on its idealistic promise.

Still another rhetorical concern has to do with institutionalization. Deborah Rhode and others insist that a plausible professional ethic must be amenable to institutionalization. ${ }^{4}$ She is right to point out that my efforts to specify how the Contextual View might be implemented are sketchy. But at least I suggest some directions. However, these directions all contemplate professional regulation-that is, regulation by nongovernmental lawyer organizations or by courts and government agencies drawing on the ideals implicit in informal lawyer practices in the manner of the common law duty of care. Legal rhetoric is simply what we would expect such actors to employ

3. See David Luban, Reason and Passion in Legal Ethics, 51 STAN. L. Rev. 873 (1999).

4. See Deborah L. Rhode, Symposium Introduction: In Pursuit of Justice, 51 STAN. L. REV. 867,872 (1999). 
in such efforts. At a minimum, such rhetoric would express the belief that the project was a public one.

Robin West points to a different kind of rhetorical stake. She argues that in some circumstances emphasizing the convergence of legality with norms of justice might have an effect opposite from the one I hope for. Instead of limiting state power by encouraging us to test the validity of the commands of state actors against a broader normative background, it might subordinate legality to state power by associating the status quo with justice. Even the broadest set of legal criteria will require some measure of formality and institutionalization for the norms that support legal judgments. In a repressive society, formalized, institutionalized norms will be repressive. In such circumstances, insisting on the connection between law and justice may simply give a patina of legitimacy to an otherwise corrupt regime. Positivism, West reminds us, at least has the virtue of insisting that we separate out the question of legality and legitimacy. 5

Mark Osiel's study of judicial rhetoric under military dictatorship in Argentina and Brazil gives numerous illustrations of West's point. For example, in 1962, the Argentine Supreme Court was pressured to allow the oath of presidential office to be administered to the military's candidate. There, one judge pointed to constitutional text to insist that the court was violating the law, but another replied in language that shows the potential affinity of Substantivism with autocracy: "He who saves the Republic cannot possibly be violating the law."6 Yet Osiel also demonstrates that Substantivism can also be associated with resistance to state repression. As he tells us, it depends on the context.

So the key question for my argument is: What kind of context is that of the contemporary American legal profession? The relevant features of this context seem to be those I mentioned above-a tendency for nominally moral reflection to be crippled by a strong impulse toward relativism, the emotional resonance for many lawyers of the reformist idealism associated with their professional role, and the greater affinity of public rhetoric with institutionalization. Although this is not a matter that permits certainty, these factors suggest promise for an ethic of legal merit.

Another consideration relevant to West's suggestion is that the current intellectual regime in professional responsibility is not the Hartian Positivism she invokes, with its rigorous insistence on separation of legal determination and legal obligation. Rather, it is the bastard doctrine that I call Moralistic Positivism, which combines the Positivist's shrunken definition of law with a

5. See Robin West, The Zealous Advocacy of Justice in a Less than Ideal Legal World, 51 STAN. L. REV. 973, 984-87 (1999).

6. Mark Osiel, Dialogue with Dictators: Judicial Resistance in Argentina and Brazil, $1995 \mathrm{~L}$. \& SOC. INQUIRY 481,495 . 
categorical injunction to obey. The bar tacitly defines law in terms of narrow criteria of jurisdiction and pedigree yet it explicitly urges categorical obedience to everything so defined. ${ }^{7}$ This doctrine seems calculated to minimize the potential of both Positivism and Substantivism to encourage independent judgment and resistance to a repressive state.

David Luban expresses another rhetorical concern that I find less compelling. He suggests that the kind of analysis I propose is too complex and sophisticated to expect of lawyers under the pressures of practice. Referring to my analysis of a tax planning case, Luban says he agrees with me on the merits, but that his students are never able to perform this analysis independently and that it may not be reasonable to expect such complex ethical analysis "of a harried tax lawyer on April 12." $\mathrm{My}$ model of lawyering, like Dworkin's Hercules, he says, is so daunting that it will lead lawyers to give up in despair at the prospect of ever measuring up.

I think Luban is underestimating here the complexity of the characteristic judgments of ordinary practitioners. True, their current ethical judgments are unsophisticated because the culture and the bar's norms discourage and even prohibit sophisticated judgments. But the strategic judgments they typically make in advancing their clients' ends, even when made under great pressure, are quite complex. Indeed complex judgment is precisely what experienced practitioners purport to give their clients and what their clients seem to seek. Sophistication is a function, not just of the time given a particular decision, but the prior experience and reflection that lies behind it:

"Can you tell me, asked Sir John Holker, "how long it took you to knock off that Nocturne?"

"Two days," replied Whistler.

"The labor of two days then is that for which you ask 200 guineas."

"No. I ask it for the knowledge of a lifetime."

Luban's students should be excused for not being able to do the analysis without assistance, but that should not preclude us from expecting more of experienced practitioners.

The more important point, however, is that the Contextual View only asks the practitioner for the best judgment she can make under the circumstances. Its main complaint about the Dominant View is that it disables the lawyer from using all the information and capabilities she has at hand.

Of course, for disciplinary purposes, we should make allowances for time limitations and other pressures. And, subject to a minimum, we should

7. See MODEL CODE OF PROFESSIONAL RESPONSIBILITY EC 7-8 (Positivist definition of law) (1980); MODEL CODE OF PROFESSIONAL RESPONSIBILITY DR 7-102(A)(8) (categorical injunction of obedience to law) (1980).

8. Luban, supra note 3, at 894.

9. From the cross-examination of James Whistler in his libel trial against John Ruskin. Quoted in Francis L. WellMan, THE ART OF Cross-ExAMINATION 45 (4th ed. 1962). 
demand more of experienced specialists than neophyte generalists. But our aspiration should be that the lawyer make the best effort she reasonably can to vindicate the relevant legal merit.

Luban undoubtedly exaggerates the sophistication of my argument. Putting that aside, however, and taking his complaint at face value, his claim is a little like saying that we should not recommend Michelangelo's works to art students because, since they could not perform at his level themselves, they would likely be demoralized by them.

\section{B. Jurisprudence}

To the extent they are about how best to describe or convey lawyers' general understandings of certain types of norms or arguments we should consider the framing issues raised by the critics as jurisprudential.

Part of David Luban's jurisprudential objections are based on a misreading of my argument. He describes me as believing that "you can find anything you want in the law." 10 He reads me as proposing a form of ethical decisionmaking that starts out with a nonlegal normative intuition (an "antecedent moral view[]") and then "translate[s]" or "reframe[s]" it into the infinitely plastic terms of the law.11 This is not at all the way I see matters.

First, my point is not that the law is infinitely plastic or co-extensive with morality. Rather I argue that the line between law and morals is hard to draw in our legal culture, precisely because we draw it at the cost of limiting the sense of obligation associated with law. What I call the Substantive tendency in the legal culture reflects the effort to incorporate in our understanding of law a sense of respect and obligation. When law departs from morals, we find it hard to justify obligation. So the very urge to respect law pushes people like Dworkin to more Substantivist understandings of it. I do not mean to deny that there are situations in which powerful moral intuitions seem to be in conflict with most relevant legal authority. I merely point out that the claims of legal obligation in these situations are questionable. One point I make is that legal ethics doctrine evades the problem of obligation by adopting a narrow, formal Positivist definition of law and conjoining it to a

10. Luban, supra note 3 , at 891 . This is a view he imputes to me, in part, because he associates both the view and me with Critical Legal Studies. However, this is not my view and it has never been the view of the Critical Legal Studies strand that has most influenced me. See ROBERTO MANGabeIRA UNGer, THE CRITICAL Legal STUdies Movement (1986). Moreover, it is not currently the view (if it ever was) of the other strand. See DUNCAN KENNEDY, A CRITIQUE OF ADJUDICATION (FIN DE SIECLE) 57-70 (1997).

11. Luban, supra note 3 , at 875,889 . I do not understand how, if it were correct, this reading would support Luban's criticism that I overestimate the role of reason and underestimate that of passion in legal ethics. If I really thought law was an ex post rationalization for a prior moral judgment, I would not be treating law as practical reason, and I say nothing inconsistent with morality being substantially based on passion. 
categorical norm of obedience. But the first move-the Positivist definition of law-is inconsistent with our understandings in most other areas of legal doctrine, and the second-the categorical injunction of obedience-is a non sequitur.

Second, I do not see law as a rationalization for a prior nonlegal judgment. Everyone in this society, and, a fortiori, lawyers, are socialized to identify and take account of legal as well as nonlegal sources of authority. (As I write, a majority of the House of Representatives is about to vote to impeach the President for morally innocuous lying in substantial part because the lying was illegal.) It follows that our strongest normative intuitions are often best described as legal, and in a broad range of situations it would be a daunting task to separate legal and nonlegal emphases.

Luban tries to show that in two of the cases I discuss the result that both he and I agree is right cannot plausibly be understood as a matter of legal merit. This effort rests on the same implausibly narrow understanding of law that I criticized in the Dominant View.

One is Paul Newman's mailbox larceny in The Verdict. I argue that stealing the phone bill is justifiable because the injury to the addressee was trivial compared to the stakes for Newman's client, and the addressee was at least passively complicit in the cover-up that threatens to thwart the enforcement of the clients' rights. Luban does not disagree with the conclusion, but he insists that, if we assume that the courts would not recognize a defense to the relevant criminal statutes in these circumstances, we can defend our mutual conclusion only on the basis of "moral" concerns that trump the "law."12

But my own views (and I do not think they are idiosyncratic) could be characterized in this manner only at the cost of significant distortion. If I try to conceive a set of values that are distinctively moral as opposed to legal, then I have no view at all on the justice of Newman's conduct. The argument I made in the book depended on the premise that the clients' right to recover damages for the death of their child caused by the defendants' negligence was a value of great weight. But as a purely moral matter, I do not believe this. I have doubts about whether society should try to provide monetary compensation to adult family members for the emotional loss arising from the death of children. Moreover, I do not believe as a moral matter that all acts of even serious negligence deserve sanction or that sanctions for such acts should take the form of private damage actions. (I am generally a supporter of doing away with the tort system in favor of expanded systems of health and social security and of occupational regulation.) So when I say that the client's interest in recovery is an important one, I mean that the law makes it important. I would not necessarily have voted to

12. See Luban, supra note 3, at $888-90$. 
give them their right. But since the legal system has institutionalized a social practice of allowing for such recovery, I think it is important that people in their situation should have a reasonable opportunity to pursue their claims.

My judgment also assumed that, given the existence of the negligence claim, the defendants and the nurse whose phone bill was stolen have duties to provide relevant information. I suppose I believe this as a moral matterthat is, I would believe it even if there were no support for it in law. However, I also view my belief as strengthened by the fact that the legal system so prescribes in various rules that the defendants and (apparently) the nurse violated.

Luban also applies his law/morals characterization to my welfare case. I argued that aggressive financial planning on behalf of a welfare recipient might be justified by the notion that there is a constitutional right to a minimally decent income. Luban does not disagree with the substance of my conclusion but sneers at my characterization of it as legal because there is no "plausible" legal argument for it.13

I supported my arguments by citing two Warren Court decisions as well as legal arguments in law reviews by two law professors, Frank Michelman and Tom Grey, that were in turn based on the text of the Constitution and Warren Court cases. ${ }^{14}$ Luban is, of course, right that more recent Supreme Court cases impliedly reject these arguments, but that hardly concludes the matter. The question is whether my disagreement with the current Supreme Court should be understood as a legal one.

To the extent that I can reconstruct the matter, I did not arrive at my belief that there is a right to a minimally decent income by reflecting on the issue without any consideration of legal materials and then looking for legal materials to support this "antecedent" conclusion. I cannot recall thinking about the issue before going to law school. At the time I made the argument that Luban now responds to, I had been a lawyer for about fifteen years and had practiced and taught welfare law for nearly ten years. I cited the Warren Court cases and the Michelman and Grey arguments, not just because they were "authority" for my belief, but because they were among the most important reasons for it.

Although I think Luban is sympathetic to the idea of welfare rights as a moral matter, he cannot seem to take the legal argument for them seriously. Why not? Surely the answer is not simply that there is no chance that the current Supreme Court will accept the argument. The probability that a court will adopt a position is a conclusive test of legal validity only for an extreme Positivist, and neither Luban nor most American lawyers are extreme Positivists. (If, for example, a right-wing Republican became President and

13. Luban, supra note 3 , at $890-92$.

14. See pp. 148-49, $234 \mathrm{nn} .12-13,235$ n.14. 
made enough appointments to the Supreme Court to cause the reversal of Roe v. Wade, would the arguments in favor of the case cease to be "legal"?) For most lawyers, what counts as legal depends in part on a substantive interpretation of the relevant authority. My view should still be considered legal if it is consistent with a minimally plausible interpretation of that authority.

\section{Rhetoric and Jurisprudence}

Of course, the question arises: plausible to whom? Surely, one can begin by answering: plausible to $m e$, or to the decisionmaker. I found this legal rhetoric the most helpful way to formulate my intuitions on the matter. Many people are troubled by the idea of individual decisionmaking. The isolated ethical decisionmaker is a lonely figure, and his decisions are likely to suffer from the absence of collective engagement and accountability. But ethical decisionmaking always has to be individual to some extent. Even a decision to defer to some group or institution requires an individual decision that the group or institution is entitled to deference.

In looking for some authority beyond the individual, the conventional approach begins and ends with the disciplinary authorities. Clearly, there are prudential reasons for considering the views of these agencies if they have the power to impose sanctions. But to treat them as a source of ethical guidance requires that the decisionmaker make a judgment about the legitimate scope of their authority. Moreover, even if we decide that the pronouncements of these agencies are entitled to great weight, these pronouncements will not provide the basis for an ethical program of any ambitiousness, since they are ambiguous or silent in many ethically urgent situations, including my welfare-planning example.

So one of the most important tasks of the lawyer who wishes to be ethically accountable to some authority beside himself and the regulatory agencies is to define a plausible set of people or institutions to be accountable to. The definition is likely to vary from lawyer to lawyer. I mentioned in the book some promising developments in alternative, voluntary bar associations. ${ }^{15}$ Anthony Alfieri and Thomas Shaffer in their comments here elaborate visions of accountability to different communities.

One reference group I had in mind in the discussion of the welfare example was that of legal aid lawyers. I was proposing the Contextual View as superior to the Dominant View for explaining to these lawyers some of their own practices and commitments. I do not think these lawyers would have had much of a problem with the idea of a legal right to welfare benefits. My

15. See p. 197. 
discussion of criminal defense was to some extent addressed to criminal defense lawyers with a similar aim in view. ${ }^{16}$

However, I also thought these analyses might be useful to these same welfare lawyers and criminal defense lawyers in explaining their positions to other lawyers, including lawyers who might not agree with their conclusions. I thought that these other lawyers might recognize and respect the arguments as part of a common professional practice, even as they disagreed with the positions.

Luban apparently disagrees, but I do not think he has adequately responded to my point. An adequate response from someone who shares my conclusion that poor people are entitled to welfare benefits would include an argument for such an entitlement that is both richer and more powerful than the ones I refer to, and not legal under some plausible criteria of legality. Luban does not give us this. Similarly, Anthony Alfieri does not follow up his complaint that my analysis depends fatally on the premises of "liberalism"17 in the only way he could make such a claim plausible-by demonstrating a better way to talk about these matters that does not depend on these premises.

The issue after all is relative. Luban quotes with favor Richard Posner's imperious dismissal of legal analysis as vacuous. ${ }^{18}$ But Posner can be so cavalier about legal thought because he has an overweening confidence in utilitarian policy analysis that Luban certainly does not share. ${ }^{19}$ For lawyers unimpressed by Posner's technique, it may turn out that legal analysis, with all its limitations, is the best alternative they have.

\section{SHAFFER AND ALFIERI}

Thomas Shaffer and Anthony Alfieri object in ways similar to Luban and West to the terms in which I try to frame ethical analysis. However, they usefully extend the critique in two directions. They both point to an alternative rhetoric-variants of communitarianism-and they situate their criticisms in particular contexts of practice. In both respects, their contributions are useful. However, I think they have more value as elaborations of my argument than as criticisms. As criticisms, they suffer from a tendency to underestimate the capacities of legal thought and to ignore certain deficiencies of the rhetoric they prefer.

16. See pp. 187-94. (1999).

17. See Anthony V. Alfieri, (Er)Race-ing an Ethic of Justice, 51 STAN. L. REv. 935, 940

18. See Luban, supra note 3, at 900 n.130.

19. See David Luban, The Posner Variations, 48 STAN. L. REv. 1001 (1991). 


\section{A. Shaffer}

Some of the value of Tom Shaffer's paper will be accessible only to those committed to his type of Christianity as the one true faith. ${ }^{20}$ But it should be useful to others in two ways. First, it draws attention to the thrilling and powerful moral vision of the Gospels, a vision that can move and inform people of many spiritual commitments. ${ }^{21}$ Second, it gives an example of a set of private moral commitments that might complement the public legal ethic that I defend. Many private moral perspectives, religious and not, converge with public ones. The private perspective may inspire and motivate people to participate in the public realm. And it may offer insights that can be translated and incorporated into public discourse.

Capital punishment is an example. Most of the Christian objections to the death penalty have secular analogues in the liberal public critique. No doubt many lawyers who participate in anti-death penalty activism draw inspiration from their religious commitments, even though their public arguments take a secular form. And the liberal public critique is influenced by Christian views.

Shaffer offers an interesting description of the way such an influence might operate. Half-heartedly acknowledging that most Christians do not treat the radical Gospel perspective with which he identifies Christianity as a basis for practical decisionmaking, Shaffer says that these Christians are likely to be "“disturbed,' at least a little bit" by his position. ${ }^{22}$ It seems likely that this vague background sentiment influences the way Christian lawyers of Shaffer's stripe construe ambiguities and reshape arguments in legal authority. To the extent that the secular rhetoric this religious vision motivates is successful, the Christian vision will have reshaped the law.

I am not sure that Shaffer intended to make this argument, but his paper suggests the argument, and it is a good one. However, Shaffer definitely makes another argument, which I think is a bad one. This other argument sees radical Christianity, not as a supplement to an ethic of justice or legal merit, but as a competitor. It sees this Christianity, not as an influence on the way some lawyers apply and articulate public norms, but as a comprehensive, direct basis for ethical decisionmaking. There may be some religious traditions suitable for this role, but I do not think Shaffer's is.

As I understand it, and as Shaffer articulates it, the Gospel tradition is an ethic of love and pacifism. It is not an ethic of justice. It is also a personal-

20. See Thomas L. Shaffer, Should a Christian Lawyer Sign Up for Simon's Practice of Justice?, 51 STAN. L. REV. 903 (1999).

21. In what I take to be a gesture towards ecumenicism, Shaffer calls his ethic alternately "Biblical" and "Christian." See Shaffer, supra note 20. It is not really a Biblical or Christian ethic; it is a Gospel ethic largely alien to the dominant tendencies of organized religion in America.

22. Id. at 910 . 
istic ethic, indifferent or hostile to abstract norms and institutional authority. It thus lends itself to a posture of humility before, empathy with, and service to, clients. It does not lend itself to resistance to client desires in the interests of remote others or impersonal values.

Shaffer's professional responsibility doctrine seems much like his immigration policy: a commitment to intense solidarity with whomever happens to be in the room..$^{23}$ However, unlike the lover's, the lawyer's role entails duties to remote others. The Gospel Ethic is not helpful in delineating such duties when they conflict with client loyalty. For this, we need the language of legal merit and justice.

Some, like Jerry Lopez, ${ }^{24}$ seem to believe that the Gospel Ethic is defensible as long as you arrange your affairs so that only poor people are likely to be in the room. Of course, most lawyers do not represent poor people at all, much less exclusively. Thus, this constraint at best limits the potential relevance of the ethic to a tiny fraction of bar (and even of Christian lawyers). Just as seriously, the Gospel Ethic, as Shaffer and Lopez present it, might undermine efforts to advance the interests of poor people on other than a one-by-one basis. In many realms, poor people are most likely to advance their interests as members of groups, communities, and organizations. Groups, communities, and organizations are constituted by normative commitments. A lawyer categorically committed to placing the interests of individual poor clients above their groups, communities, and organizations undermines the collective capacities of their constituents. ${ }^{25}$

Another problem concerns the attitude of this ethic toward resistance to state power. The Gospels tend to prescribe indifference, not resistance, to state power. At the same time that they deny the ethical authority of the state, they encourage acquiescence to the demands of state officials ("render unto Caesar"). Shaffer portrays my views as statist, but an ethic of justice and legal merit is committed to public values, not the state, and public values often provide a basis for resisting state officials. Statism seems a greater danger with Shaffer's ethic because that ethic empties the public realm of moral authority without supplying any evident alternative basis for resistance. ${ }^{26}$

23. See id. at 911-13.

24. See Gerald P. Lopez, Rebellious lawyering: One Chicano's Vision of ProGRESSIVE LAW PRACTICE (1992).

25. See William H. Simon, The Dark Secret of Progressive Lawyering: A Comment on Poverty Law Scholarship in the Post-Reagan, Post-Modern Era, 48 U. MIAMI L. REV. 1099 (1994).

26. Perhaps Shaffer could elaborate his view to meet this problem, but I am troubled that, after portraying the INS and the immigration laws as deeply evil, Shaffer expresses reluctance to lie to the INS in order to vindicate a just claim that would otherwise be denied.' See Shaffer, supra note 20 , at 912 \& n.50, 913 n.53. I do not mean to suggest that, even on Shaffer's assumptions about the justice of immigration policy, the question of lying is not a difficult one, but here Shaffer's position seems considerably more statist than my own. 


\section{B. Anthony Alfieri}

Like Shaffer, Alfieri is suspicious of the rhetoric of individualism and justice. He wants to re-orient legal ethics toward more communitarian terms. He illustrates his preferred approach with a series of fascinating analyses of the use of racial rhetoric and imagery in recent criminal cases.

His most extended analysis focuses on the trial of Damian Williams and Henry Watson, two black men, for the brutal and racially-motivated beating of a white man during the L.A. riots following the Rodney King acquittal. ${ }^{27}$ Defense counsel presented on their behalf what Alfieri calls a "selfsubordinating" defense, one that played on images of black men as uncontrollably violent in order to argue for exoneration on the basis of diminished capacity. The lawyers presented academic experts to testify that situations of disorder, such as the riot, have an intoxicating effect that disables normal impulses of self-control. Although these generalizations were not explicitly framed in racial terms, in the context of the case, they gained resonance from popular prejudices about the violent proclivities of black men.

Assuming that such tactics are legitimated by the dominant view of legal ethics and individualistic or "liberal" approaches to the problem, Alfieri argues for an approach that recognizes some responsibility for the effect of such tactics in propagating and confirming offensive and bigoted images of African Americans. He thinks that lawyers should consider the probable "community" harm from such tactics in deciding whether to employ them.

Alfieri is quite vague on the dimensions of the community he seeks to protect. Is it just African Americans, or a broader community? He is also vague on how he would like the normative analysis to proceed. Does it make any difference whether the defendants are factually guilty? That the process is generally fair or fundamentally unfair in some respect? Do we consider the potential community harm only from the use of racial imagery or should we consider the community harm of a substantively wrong outcome, such as reduced deterrence in the case of wrongful acquittal, greater insecurity in the case of a wrongful conviction? How do we weigh the interests of the particular defendants against those of the broader community?

It is no shame to Alfieri that he fails to resolve all these questions, but until he does resolve them in some language that dispenses with the terms of legal merit and justice, I will not be impressed by his dismissal of my approach. I think any plausible resolution will end up employing such terms. As long as the decisionmaker recognizes either multiple communities with competing interests and claims or competing interests and claims within

27. See Alfieri, supra note 17 , at 942 ; see also Anthony V. Alfieri, Defending Racial Violence, 95 COLUM. L. REV. 800 (1995). 
communities, she is likely to need the language of justice and legal merit to deal with them.

I can offer just one example here of a way in which my "legal merit" analysis might be helpful. This analysis asks us, before we reach questions of substantive merit, to look to procedural norms and practices and assess their capacity for resolving the issue. Only where we see significant procedural inadequacy or breakdown need we assume major responsibility for assessing substantive merits. ${ }^{28}$ From this perspective, a critical question Alfieri does not entertain is, why do defense counsel have the option of presenting the "self-subordinating" defense at all? As Alfieri describes it, it seems the worst kind of junk science-academic charlatanism clothing a blatant appeal to racial prejudice. One would expect the judge to have excluded it, the prosecutor to have easily discredited it, and the jury to have disregarded it. The ethical issue would then be moot.

That the issue is not moot, and that the defense is apparently a strategically promising option, requires us to consider two possibilities. First, maybe the "self-subordinating" defense promises more probative value on the merits or less social harm than we initially supposed. We ought to reassess our initial impression in light of the fact that other actors appear to perceive the situation differently. A second possibility is that one or more of these other actors is incapable of competently or responsibly performing their role. If so, then defense counsel may need to assume more responsibility. There may be a reason why they should refuse to present the defense even if it is strategically advantageous. In my view, however, the procedural breakdown is an important part of the case for restraint.

No communitarian analysis could dispense with this type of procedural consideration, and to the extent that it incorporates it, the analysis will be harder to distinguish from the legal merit approach.

\section{ROSTAIN}

Tanina Rostain raises a different issue. ${ }^{29}$ She warns that adoption of the Contextual approach might not produce results dramatically different from the current ethical regime or, worse, might exacerbate existing pro-client biases. She says that, despite the profession's exhortation to maintain independent judgment, lawyers tend to adopt their clients' perspectives on the world, and hence their Contextual judgments will be biased toward these perspectives.

28. See pp. 139-44.

29. See Tanina Rostain, Waking Up from Uneasy Dreams: Professional Context, Discretionary Judgment, and The Practice of Justice, 51 STAN. L. REV. 955 (1999). 
Rostain's assertion about bias is based on a study of current lawyer attitudes. She does not consider the extent to which these attitudes reflect the current ethical regime and might be mitigated under a reformed one. Although the bar currently encourages the lawyer to maintain a perspective independent of his client's interests, it gives him relatively little use for such a perspective. Responsibilities to nonclients now require only fairly coarse judgments based on relatively bright-line norms. By requiring more complex judgments, a Contextual regime would give lawyers stronger moral reason to cultivate an independent perspective.

I argued in the book that if lawyers have relations with clients that engender bias, they and their clients also have relations with third parties that involve both material incentives and psychological pressures toward cognitive detachment from clients. I mentioned various reforms that might strengthen these incentives and pressures. ${ }^{30}$

If Rostain is right that pro-client bias would persist or increase under a Contextual regime, then such a regime could respond to it directly. On the level of individual decisionmaking, we should strive to make practitioners aware of the bias and encourage them, if they cannot transcend it, to at least compensate for it in their decisionmaking. A lawyer who recognizes he has a pro-client bias should, in hard cases, be less confident about conclusions that sacrifice nonclient to client interests than about conclusions that sacrifice client to nonclient interests. She should be more committed to reconsidering the former conclusions. She should strive harder to avoid circumstances in which her decision is not subject to check or review by other institutions and actors not subject to her bias. ${ }^{31}$

From the point of view of the regulator, pro-client cognitive bias would simply reinforce the tendency induced by material incentives for lawyers to transgress disproportionately against third party and public interests and in favor of client interests. Regulators can respond by focusing enforcement efforts on pro-client noncompliance. They can elaborate their norms more specifically to minimize ambiguity in such areas. (Recall, however, that elaboration does not need to take the form of categorical rules; it can occur through rebuttable presumptions and illustrative cases.)

Finally, I have to reassert my conviction that the concerns about implementation of the sort Rostain focuses on should not be allowed to swamp consideration of the ideal. We cannot coherently talk about social engineering until we are clear about our goals, and too much legal ethics discussion strives to develop technical insights on the basis of unexamined normative intuitions.

30. See pp. 203-14.

31. In my discussion of the Union Representation Election Case at pp. 151-56, I gave a brief illustration of how a lawyer might take account of awareness of his own bias in decisionmaking. 
Moreover, we know so little about the empirical dynamics of practice that it may be pointless, or at least premature, to introduce technical considerations into legal ethics. Rostain's assertions about bias have the most meager evidentiary basis-responses to a survey of 250 lawyers in one town on issues only ambiguously related to her point. ${ }^{32}$ John Ruskin's observation that it is easier to figure out what is just in the immediate circumstances than to predict and weigh the global consequences of our actions $\mathrm{s}^{33}$ seems applicable to the contemporary circumstances of legal ethics.

32. The principal support offered for her bias claim is a set of survey responses from 250 Chicago lawyers indicating that most of the reforms these lawyers thought desirable in the areas in which they practiced favored their clients. See Rostain, supra note 29, at 961-64 (citing ROBERT L. NELSON, PARTNERS WITH POWER (1988) and Robert Nelson, Ideology, Practice, and Professional Autonomy: Social Values and Client Relationships in the Large Law Firm, 37 STAN. L. REV. 503 (1985)). However, asking what is a desirable reform is not the same thing as asking what is just, which is the question that the Contextual View asks.

33. See JOHN RUSKIN, UNTO THIS LAST 117-18 (1968). 